\title{
Alexander Pruss. Die Amuq-Terrakotten. Untersuchungen zu den Terrakotta-Figuren des 2. und 1. Jahrtausends v. Chr. aus den Grabungen des Oriental Institute Chicago in der Amuq-Ebene
}

\section{Astrid Nunn}

\section{OpenEdition}

\section{Journals}

Édition électronique

URL : http://journals.openedition.org/abstractairanica/40403

DOI : 10.4000/abstractairanica.40403

ISSN : 1961-960X

Éditeur :

CNRS (UMR 7528 Mondes iraniens et indiens), Éditions de l'IFRI

Édition imprimée

Date de publication : 1 décembre 2013

ISSN : 0240-8910

Référence électronique

Astrid Nunn, «Alexander Pruss. Die Amuq-Terrakotten. Untersuchungen zu den Terrakotta-Figuren des 2. und 1. Jahrtausends v. Chr. aus den Grabungen des Oriental Institute Chicago in der Amuq-Ebene», Abstracta Iranica [En ligne], Volume 32-33 | 2013, document 108, mis en ligne le 01 juillet 2016, consulté le 27 septembre 2020. URL : http://journals.openedition.org/abstractairanica/40403 ; DOI : https://doi.org/10.4000/abstractairanica.40403

Ce document a été généré automatiquement le 27 septembre 2020.

Tous droits réservés 


\section{Alexander Pruss. Die Amuq- Terrakotten. Untersuchungen zu den Terrakotta-Figuren des 2. und 1. Jahrtausends v. Chr. aus den Grabungen des Oriental Institute Chicago in der Amuq-Ebene}

Astrid Nunn

\section{RÉFÉRENCE}

Alexander Pruss. Die Amuq-Terrakotten. Untersuchungen zu den Terrakotta-Figuren des 2. und 1. Jahrtausends v. Chr. aus den Grabungen des Oriental Institute Chicago in der Amuq-Ebene. Turnhout, Brepols, 2010, 469 p. (Subartu 26)

1 Des 570 terres cuites provenant des sites de la plaine de l'Amuq, seul un peu plus d'une centaine sont d'époque achéménide (p. 328-329). Il s'agit de plaques d'Astarté (p. 162-197, $\mathrm{n}^{\circ}$ 177-180, 182-200), de cavaliers "perses» et de quelques cavalières (p. 256-302, $n^{\circ}$ 181, 368-456). Cette étude un peu difficile à lire, est bien documentée et offre un aperçu de la coroplastie de la Syrie entière. 


\section{AUTEURS}

\section{ASTRID NUNN}

Université de Munich 